\title{
SOME SPECIFIC FEATURES OF THE LATE ORDOVICIAN EVOLUTION IN THE BALTIC BASIN
}

In his work Männil (Мянниль, 1966) has described the history of the Ordovician Baltic basin. The succeeding research, especially in lithology and microfauna, together with the new data on macrofossils, have enabled us to distinguish some new aspects in its evolution, mainly in North Estonian and Lithuanian confacies belts.

Our late colleague L. Põlma distinguished two epochs in the PostTremadocian evolution of the Baltic basin (Пылма, 1975, 1982; Пылма, Хинтс, 1982). The first epoch comprises the period from the Latorp to the Keila time. It corresponds to two evolutionary stages of the Baltic basin distinguished by Männil in 1966 - the Arenigian-Llandeilian and early Caradocian Stages. The second (late) epoch comprises the period from the Oandu to the Porkuni time (Late Caradocian and Ashgillian Stages by Männil).

For these two epochs clearly different models of sedimentation were proposed (Хинтс, Пылма, 1981). At the first epoch the sedimentation took place in the conditions of an extremely flat bottom relief of the basin during the transgression (up to the Uhaku time) and its stabilization (at the last half of the epoch).

The rocks of the first epoch are characterized by microcrystalline matrix, rare pelletal material, high content of skeletal debris $(30-40 \%)$ and its even distribution. Endemics are quite typical in benthic faunas, the species diversity is high but the quantity of specimens is usually low. Litho- and biofacial transitions are gradual. For this type of sedimentation the acceptable model was proposed by Anderson (1971, p. 295, model I).

The second epoch is characterized by predominantly regressive nature of sedimentation alternating with transgression phases. The model of sedimentation for that type of a basin has a relatively deep central part, like the Silurian basin (Нестор, Эйнасто, 1977). The rocks of the second epoch are characterized mostly by cryptocrystalline matrix, pelletal material is widespread in the northern (Estonian) confacies belt. The mean content of skeletal debris is only $10-20 \%$, occurring unevenly with the accumulations by layers. In the composition of the faunal associations there are lots of cosmopolitan species and immigrants from other Ordovician basins. The periodical development of bioherms is typical for this epoch. The litho- and biofacial transitions between the confacies belts are quite rapid.

Changes in the type of carbonate sedimentation in the East Baltic Region of the Baltic basin were controlled by tectonical movements, changes in the climate (it turned more arid) and also by fluctuations of the sea level. 
L. Põlma* noted that during the second epoch the alternation of rather clearly distinguished lithotypes took place, which cannot be said about the first epoch. He treated those lithotypes in the rank of cycles where every cyclite consists of two parts (Fig. 1): 1) the lower, relatively clayey part (predominating are argillaceous limestones and marls), and 2) the upper part, represented by pure (without terrigenous admixture) aphanitic, microcrystalline limestones. The first half of a cyclite is transgressive, the second half - regressive, during which the inflow of terrigenous material into the sedimentary basin practically ceased, and rather homogeneous carbonate muds or cryptocrystalline (detrital) material were formed. Bioherms were distributed in the upper part of the cyclite. As one possible reason for such an alternation of clayey and pure carbonate deposits L. Põlma considered the climatic factor.

The most considerable change in carbonate sedimentation takes place from the end of the Keila up to the beginning of the Oandu time. In the fauna it is clearly expressed at the boundary between the Keila and Oandu Regional Stages, the most remarkable boundary in the Post-Tremadocian Ordovician sections of the East Baltic confacies belts. In our stratigraphical scheme this boundary corresponds to the boundary between

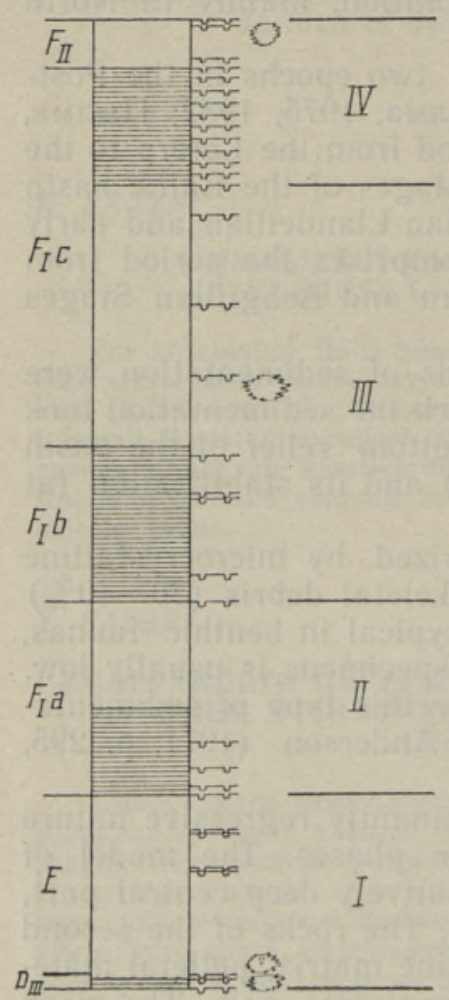

Fig. 1. The regional stages (left) and the corresponding cyclites (right, I-IV) of the Late Ordovician sedimentary cycle in the East Baltic. The thick-lined cuts of the section show the lower clayey parts of the cyclites (after L. Põlma). the Climacograptus wilsoni and Dicranograptus clingani Zones. Here a very sharp change in the composition of bryozoans, brachiopods, trilobites, ostracodes, chitinozoans and other groups of macro- and microfauna is recorded, occurring mainly at the species level.

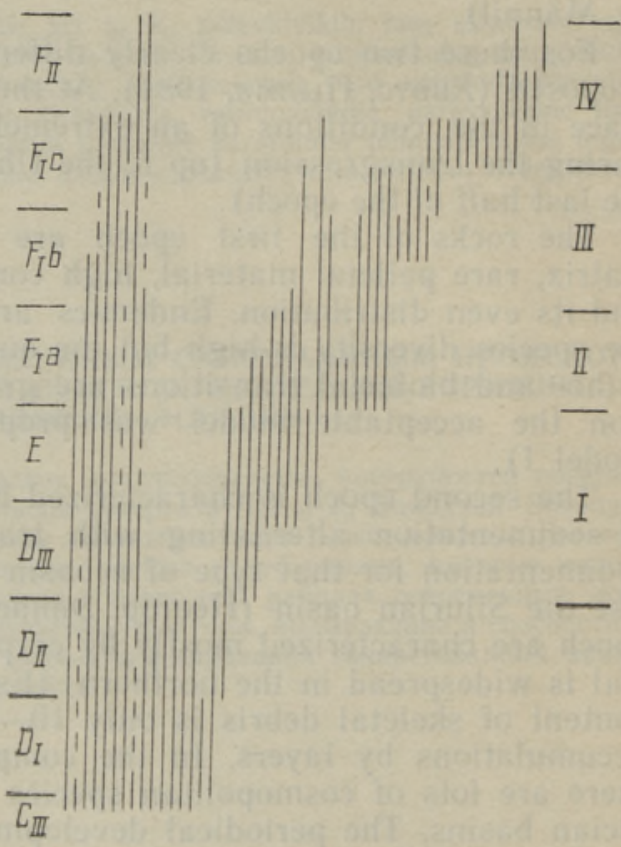

Fig. 2. Distribution of chitinozoans in the late Middle and Upper Ordovician of the East Baltic.

\footnotetext{
* Отчет по теме «Стратотипы верхнего ордовика и лландовери Эстонии (Report in manuscript "Stratotypes of the Upper Ordovician and Llandovery in Estonia"). Институт геологии АН ЭССР, 1987. Центральный научный архив АН ЭССР, фонд 16.
} 
In the central part of the basin the boundary between the Keila and Oandu Regional Stages falls into the upper part of the Blidene marls succeeded by graptolitic argillites of the Mossen Formation. Within that interval the Late Ordovician deep water faunal associations are formed in the East Baltic, much differing from those appearing in shallow water conditions.
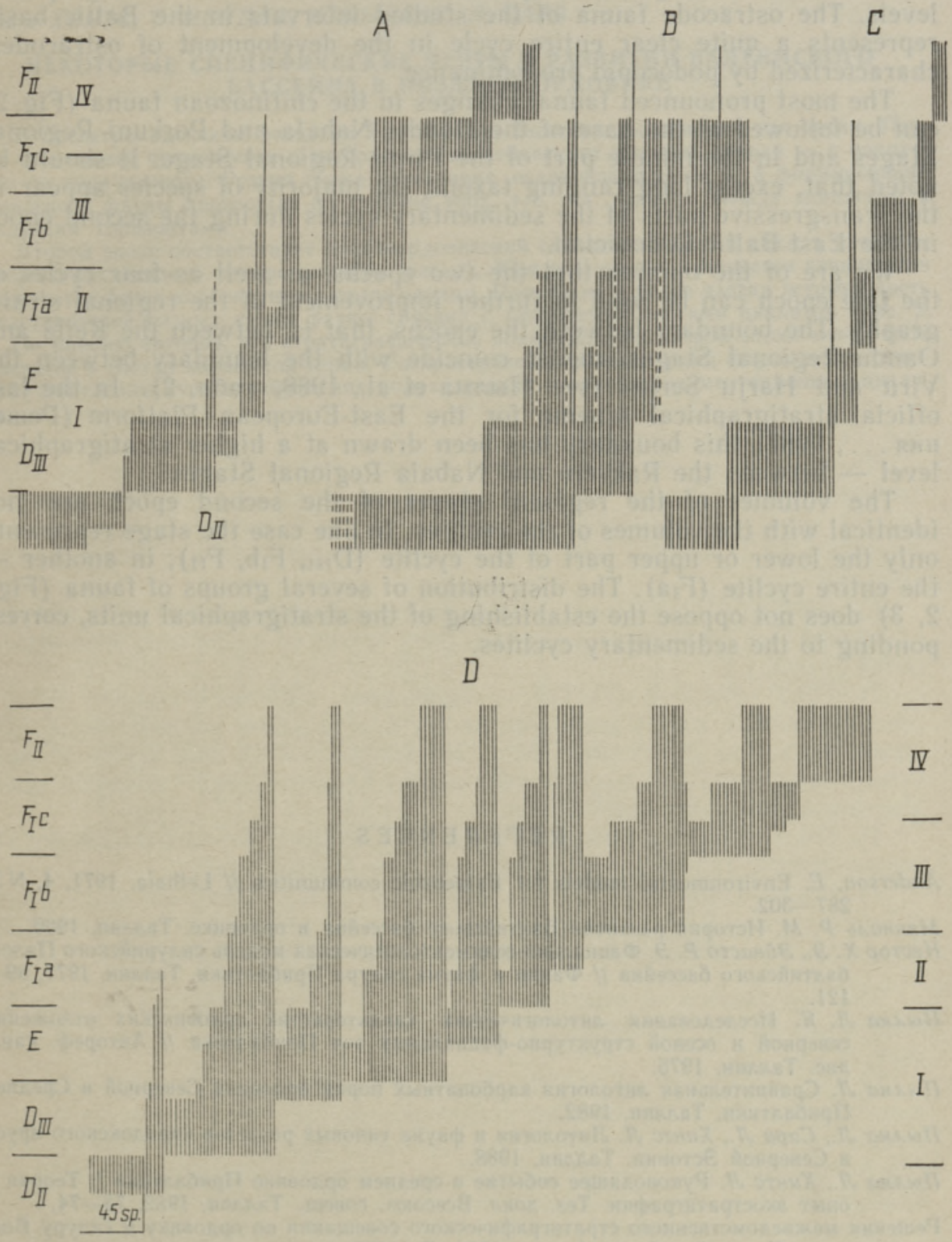

Fig. 3. Distribution of the Upper Ordovician brachiopods (A) in the North East Baltic (by A. Rõomusoks, L. Hints), bryozoans (B) in the South East Baltic (by V. Pushkin), echinoderms (C) in the North East Baltic (by R. Yeltysheva, G. Stukalina) and ostracodes (D) in the North East Baltic (by T. Meidla, L. Sarv). In Figs 2 and 3 each vertical line corresponds to one species. 
The clayey cycles of the second epoch of sedimentation are characterized by the appearance of abundant new species of brachiopods, bryozoans, echinoderms and chitinozoans (Figs 2,3). This is especially well observed at the lower boundaries of the Oandu Regional Stage, the Paekna Formation of the Nabala Regional Stage, the Vormsi Regional Stage and the Adila Formation of the Pirgu Regional Stage. New species of brachiopods, echinoderms and bryozoans appeared most abundantly in the Oandu marls and Vormsi clayey limestones. Recent data on about 200 ostracode species at the interval from the Oandu up to the Porkuni Regional Stages show a distinct change in the species content at these two stratigraphical levels. The ostracode fauna of the studied intervals in the Baltic basin represents a quite clear entire cycle in the development of ostracodes, characterized by podocopid predominance.

The most pronounced faunal changes in the chitinozoan fauna (Fig. 2) can be followed at the base of the Oandu, Nabala and Porkuni Regional Stages and in the middle part of the Pirgu Regional Stage. It should be noted that, except long ranging taxons, the majority of species appear in the transgressive parts of the sedimentary cycles during the second epoch in the East Baltic Ordovician.

We are of the opinion that the two epochs, as well as four cycles of the late epoch can be used in further improvement of the regional stratigraphy. The boundary between the epochs, that is, between the Keila and Oandu Regional Stages, should coincide with the boundary between the Viru and Harju Series (see Пылма et al., 1988, табл. 2). In the last official stratigraphical scheme for the East-European Platform (Решения ..., 1987) this boundary has been drawn at a higher stratigraphical level - between the Rakvere and Nabala Regional Stages.

The volumes of the regional stages of the second epoch are not identical with the volumes of the cyclites. In one case the stage represents only the lower or upper part of the cyclite $\left(D_{I I I}, F_{I} b, F_{I I}\right)$, in another the entire cyclite $\left(\mathrm{F}_{\mathrm{I}} \mathrm{a}\right)$. The distribution of several groups of fauna (Figs $2,3)$ does not oppose the establishing of the stratigraphical units, corresponding to the sedimentary cyclites.

\section{REFERENCES}

Anderson, E. Environmental models for Palaeozoic communities // Lethaia, 1971, 4, N 3, $287-302$.

Мянниль Р. М. История развития Балтийского бассейна в ордовике. Таллин, 1966.

Нестор Х. Э., Эйнасто Р. Э. Фациально-седиментологическая модель силурийского Палеобалтийского бассейна // Фации и фауна силура Прибалтики. Таллин, 1977, 89121.

Пылма Л. Я. Исследования литологических характеристик ордовикскнх отложений северной и осевой структурно-фациальных зон Прибалтики // Автореф. канд. дис. Таллин, 1975.

Пылма Л. Сравнительная литология карбонатных пород ордовика Северной и Средней Прибалтики. Таллин, 1982.

Пылма Л., Сарв Л., Хинтс Л. Литология и фауна типовых разрезов карадокского яруса в Северной Эстонии. Таллин, 1988.

Пылма Л., Хинтс Л. Руководящее событне в среднем ордовике Прибалтики // Теория и опыт экостратиграфин. Тез. докл. Всесоюз. совещ. Таллин, 1982, 73-74.

Решения межведомственного стратиграфического совещания по ордовику и силуру Восточно-Европейской платформы, 1984. Л., 1987.

Хинтс Л., Пылма Л. Распределение остатков ископаемых организмов (макрофоссилий и детрита) в среднем ордовике Прибалтики // Изв. АН ЭССР. Геол., 1981, 30, № 3, 89-97. 


\section{MÕNEDEST BALTI BASSEINI ARENGU ISEARASUSTEST HILISORDOVIITSIUMIS}

Artiklis on käsitletud setete kujunemise, nende tsüklilise ehituse ja mõnede faunarühmade leviku iseärasusi. Kuna kogu hilisordoviitsiumile iseloomulikud tingimused eksisteerisid ka Oandu ja Rakvere eal, peetakse võimalikuks vastavad lademed arvata Harju seeria koosseisu. Viimase piires aga on võimalik sedimentatsioonitsükliitide mahule vastavate stratigraafiliste ühikute väljaarendamine.

\section{Линда ХИНТС, Т. МЕИДЛА, Я. НЫЛВАК, Л. САРВ \\ НЕКОТОРЫЕ СПЕЦИФИЧЕСКИЕ ЧЕРТЫ В РАЗВИТИИ БАЛТИИСКОГО БАССЕИНА В ПОЗДНЕМ ОРДОВИКЕ}

В послетремадокском развитии Балтийского бассейна выделяются две эпохи. Первая охватывает промежуток с латорпского до кейлаского времени, вторая - с оандуского до поркуниского. Резкая смена в условиях осадконакопления и в формировании комплексов фауны произошла на границе эпох, т. е. на границе между кейласким и оандуским горизонтами.

Второй эпохе соответствует позднеордовикский седиментационный цикл, в пределах которого установлено четыре циклита (рис. 1). Каждый циклит начинается глинистыми и кончается более карбонатными отложениями. Появление и более частая встречаемость представителей разных групп фауны связана с глинистыми частями циклитов (рис. 2, 3). По мнению авторов, все стратиграфические подразделения второй эпохи могут быть включены в состав харьюской серии. Распространение разных групп фауны не противоречит выделению стратиграфических подразделений в объеме седиментационных циклитов. 